http://dx.doi.org/10.4314/jae.v19i2.8

\title{
Factors Influencing Smallholder Farmers Participation in IFAD-Community Based Agricultural and Rural Development Project in Katsina State
}

\author{
Abdullahi Alhaji Jamilu \\ National Agricultural Extension and Research Liaison Services, \\ A.B.U Zaria \\ Email: alhjamilu30@gmail.com Phone: +2348028448193 \\ Atala T. K. \\ Department of Agricultural Economics and Rural Sociology, \\ A.B.U Zaria \\ Akpoko J. G. \\ Department of Agricultural Economics and Rural Sociology, \\ A.B.U Zaria \\ Sanni S. A. \\ Department of Agricultural Economics and Rural Sociology, \\ A.B.U Zaria
}

\section{Abstract}

This study assessed Factors Influencing smallholder farmers' participation in IFAD-Community Based Agricultural and Rural Development Project in Katsina State. Data for the study were obtained by the use of structured questionnaire. Multistage sampling technique was employed to select the 698 respondents. In the first stage, a purposive sampling technique was used to select one village area that had the highest participating farmers out of the three village areas in each LGA. The second stage involved the use of proportionate random sampling technique to select $12 \%$ of the population. This gave a total of three hundred and fourty nine (349) participating farmers from the twelve participating village areas. Also, 349 non-participating farmers were selected from neighbouring communities using proportionate random sampling. Descriptive statistics and logit regression analysis were used to analyze the data. The result shows that $23 \%$ of the participating farmers were between the ages of 46-50 years and 91\% were males. The result also shows that level of education with coefficient value of (-0.309), household size (-0.041), farm size (0.801), membership of cooperative (0.547) and extension contact (-0.283) were the factors influencing smallholder farmers participation in the project. The result further shows that inadequate capital, inadequate agricultural credits and inadequate storage facilities were the major constraints to participation in the programme. The study recommends that extension workers should assist farmers to form viable co-operative associations and where they are in existence, efforts should be made to strengthen them for easy access to credit, farm inputs and markets for their agricultural products.

Keywords: Small holder farmer participation, Rural development and extension workers. 


\section{Introduction}

Approximately 1.5 billion people are engaged in smallholder agriculture across the world. They include $75 \%$ of the world's poorest people, whose food, income and livelihood prospects depend on agriculture (Andrea 2014). Peasantry is the dominant mode of agricultural production and livelihood in Nigeria with over 70 percent of the population engaged in agricultural activities as a career and largely feeding the nation (Atala and Hassan, 2012). Schubert (1994) asserted that the major source of income of the poor is agriculture and poverty is more prevalent among smallholder farmers. Previous studies established that poverty incidence is as high as $67 \%$ in the North West (IDEP, 2006) to which Katsina state belongs. Hence, poverty incidence in the state, as in the major part of the country, is a matter of urgent policy concern. Poverty reduction in Nigeria will not be possible without rapid agricultural growth. Babatunde (2006) reported that the concern over increasing poverty levels especially in the developing countries such as Nigeria and the need for its alleviation as a means of improving the standard of living of the people has led to the conceptualization and implementation of various poverty alleviation programmes worldwide. Among which is the International Fund for Agricultural Development Community Based Agriculture and Rural Development Project (IFAD-CBARDP).

The International Fund for Agricultural Development (IFAD) support to the Nigerian Government's poverty reduction programme in rural areas targets large numbers of smallholder farmers and is essentially people-centered. IFAD supports programmes and projects that work with communities, with smallholder farmers as the key players (IFAD, 2013). The International Fund for Agricultural Development Community Based Agriculture and Rural Development Programme (IFAD-CBARDP) is an integrated agriculture and rural development programme. The programme was launched on $31^{\text {st }}$ January 2003 with a completion date of $31^{\text {st }}$ march 2013 in eight states of northern Nigerian where poverty is widespread namely; Jigawa, Kano, Katsina, Kebbi, Sokoto and Zamfara in the north-west, and Borno and Yobe in the north-east (Bukar, 2005). It builds on the project previous experience with implementing community-based projects in the northern states of Sokoto and Katsina, and its objective is to help the most vulnerable groups improve their incomes and living conditions.

The major objectives include-

i. the improvement of the livelihoods and living conditions of the rural poor with emphasis on women and other vulnerable groups;

ii. empowerment of poor rural communities to enable them identify their needs, implement a broad range of agricultural and rural development (ARD) initiatives, and

iii. Institutionalise and internalise community-driven development (CDD) into government policies and procedures. 
Participation in extension is the process of communication among farmers and extension workers, during which the farmers take the leading role to analyze their situation to plan, implement and evaluate development activities. Participation according to Aref at al. (2010) is the direct involvement of marginalized groups in a development process, which aims to build people's capabilities to have access to and control of resources, benefits and opportunities towards self-reliance and improved quality of life. Studies have shown that farmers have different reasons for participation in agricultural development programmes. In a study conducted by Edi et al. (2007) on factors affecting farmers' participation in Agric environmental measures reported that projects that provided easy access to farming inputs, and are environmentally friendly and provide adequate leisure time encouraged participation.

\section{Justification of the study}

Most of the farmers in Katsina State are smallholder farmers that depend mostly on agriculture for their livelihoods. They rely on income from this occupation to finance their investments and domestic needs. By determining the factors that influence farmers participation in IFAD-CBARDP activities in the study area, this research work would provide guidance to the IFAD-CBARDP stakeholders. As such, the added knowledge on which factors have the greatest influence on IFAD-CBARDP participation will help administrators make more informed decisions on how to promote IFAD-CBARDP recommended agronomical practices within the study area and beyond.

The specific objectives of this study were to:

i. describe the socio-economic characteristics of the smallholder crop farmers in the study area;

ii. determine the socio-economic factors influencing farmers participation in the programme and;

iii. identify the major constraints to the effective participation of farmers in the programme.

\section{Hypothesis}

The null hypothesis tested in this study was:

Ho: Farmers' socio-economic factors have no significant influence on participation in the project.

\section{Methodology}

This study assessed smallholder farmers' participation in IFAD-Community Based Agricultural and Rural Development Project in Katsina State. Data for the study were obtained by the use of structured questionnaire. A multistage sampling technique was employed to select the 698 respondents. In the first stage, a purposive sampling was used to select one village area that had the highest participating farmers out of the three village areas in each Local Government Area. The second stage involved the use of proportionate random 
sampling technique to select twelve per cent $(12 \%)$ of the population from the list of the participating farmers obtained from the extension agent of each of the selected villages. This gave a total of three hundred and forty nine (349) participating farmers from the twelve participating village areas. Also three hundred and forty nine (349) non-participating farmers were selected from neighbouring communities using random digit number to get the corresponding sample. The non-participants were used as control group to justify the use of the logit regression model for the study. Percentages, means and logit regression analysis were used to analyse the data.

\section{Table 1: Sampling design}

\begin{tabular}{|c|c|c|c|c|c|c|}
\hline \multirow[t]{2}{*}{ LGA } & \multicolumn{3}{|c|}{ Participants } & \multicolumn{3}{|c|}{ Non-participants } \\
\hline & $\begin{array}{l}\text { selected } \\
\text { Participating } \\
\text { Villages }\end{array}$ & $\begin{array}{l}\text { Participating } \\
\text { Farmers in } \\
\text { the } \\
\text { Villages }\end{array}$ & $\begin{array}{l}\text { selected } \\
\text { Participat } \\
\text { ing } \\
\text { farmers } \\
(12 \%)\end{array}$ & $\begin{array}{l}\text { Selected non- } \\
\text { Participating } \\
\text { Villages }\end{array}$ & $\begin{array}{l}\text { non- } \\
\text { Participating } \\
\text { Farmers in } \\
\text { the } \\
\text { Villages }\end{array}$ & $\begin{array}{l}\text { Selected non- } \\
\text { Participating } \\
\text { farmers }\end{array}$ \\
\hline Danja & Kahutu & 492 & 59 & Dabai & 552 & 59 \\
\hline Kurfi & Rawayau & 280 & 34 & Gwanzo & 378 & 34 \\
\hline Musawa & Tsabe & 220 & 26 & Jikamshi & 380 & 26 \\
\hline Bakori & Jargaba & 180 & 22 & Makera & 447 & 22 \\
\hline Baure & Hurtumi & 135 & 16 & Kawari & 219 & 16 \\
\hline Bindawa & Yangora & 171 & 21 & Doro & 320 & 21 \\
\hline Dutsi & Karawa & 172 & 21 & Danaunai & 264 & 21 \\
\hline Jibia & Daga & 125 & 15 & Bugaje & 218 & 15 \\
\hline Kaita & Baawa & 415 & 50 & Yandaki & 643 & 50 \\
\hline Batsari & Yauyau & 293 & 35 & Madaddabi & 432 & 35 \\
\hline Dutsinma & Yanshantuna & 165 & 20 & Karofi & 241 & 20 \\
\hline Kusada & Kofa & 246 & 30 & Dan gamau & 534 & 30 \\
\hline Total & & 2894 & 349 & & 4628 & 349 \\
\hline
\end{tabular}

Source: Reconnaissance Survey 2013

\section{Logit Model Specification}

Participation in IFAD-CBARDP was the dependent variable and represented in the model by binary variable taking the value of 1 if the farmer had participated and 0 if otherwise. The cumulative logistic probability function is specified as:

$P_{i}=F\left(Z_{i}\right)=F\left[\alpha+\sum_{i=1}^{n} \beta_{i} X_{i}\right]=\left[\frac{1}{1+e^{-\left(\alpha+\sum \beta_{i} X_{i}\right)}}\right]$

Where, Pi represents that the probability that $\mathrm{i}^{\text {th }}$ farmer being participating given $\mathrm{Xi}, \mathrm{Xi}$ represents the ith farmer's explanatory variables, $\mathrm{i}=1,2,3 . ., \mathrm{n} ; \mathrm{Zi}$ a linear function of $n$ explanatory variables $(X i)$, e represents the base of natural 
logarithms; $\alpha$ and $\beta_{i}$ are regression parameters to be estimated in the model, where $\alpha$ the intercept and $\beta_{1}, \beta_{2} \ldots \beta n$ are slope coefficient of the equation.

The model can also be written in terms of the log of the odds ratio (the probability that the farmer is participating $(\mathrm{Pi}))$ to the probability that is notparticipating (1-Pi) (Gujrati, 2004). The probability that is non-participating (1$\mathrm{Pi}$ ) is defined by:

$$
\left(1-P_{i}\right)=\frac{1}{1+e^{z_{i}}}
$$

Using equation (1) and (2), the odds ratio becomes

$$
\left(\frac{P_{i}}{1-P_{i}}\right)=\left[\frac{1+e^{Z_{i}}}{1+e^{-Z_{i}}}\right]=e^{Z_{i}}
$$

Alternatively,

$$
\left(\frac{P_{i}}{1-P_{i}}\right)=\left[\frac{1+e^{Z_{i}}}{1+e^{-Z_{i}}}\right]=e^{\left(\alpha+\sum \beta_{i} X_{i}\right)}
$$

Taking the natural logarithms of odds ratio of equation (4) it results as,

$Z_{i}=\ln \left[\frac{P_{i}}{1-P_{i}}\right]=\ln e^{\left[\alpha+\Sigma \beta_{i} X_{i}\right]}=\alpha+\beta_{1} X_{1}+\beta_{2} X_{2} \ldots \beta_{n} X_{n}+U$

If the disturbance term ( $\mathrm{Ui})$ is introduced to the model, the logit model becomes

$$
Z_{i}=\alpha+\beta_{1} X_{1}+\beta_{2} X_{2} \ldots \beta_{n} X_{n}+\mu_{i}
$$

The logit model is specified as:

$\log =\left(\frac{P}{R-P}\right)=$

\section{Linearizing}

$Y=a+b_{1} x_{1}+b_{2} x_{2}+b_{3} x_{3}+---b_{8} x_{8}+u$

Where: 
$\mathrm{Y}=$ Participation $\left(\sum_{0=\text { No=not Participating }}^{1=\text { yes }=\text { Participating }}\right)$

$\mathrm{X}_{1}=$ Age (in years)

$\mathrm{X}_{2}=$ Level of education (years)

$\mathrm{X}_{3}=$ Family size (number of persons)

$\mathrm{X}_{4}=$ Farm size (ha)

$\mathrm{X}_{5}=\operatorname{Sex}($ male $=1 ;$ female $=2)$

$\mathrm{X}_{6}=$ Membership of co-operative (number)

$\mathrm{X}_{7}=$ Extension contact (no. of visit)

$\mathrm{X}_{8}=$ Amount of credit used $(\mathrm{A})$

$\mathrm{a}=$ Constant

$b_{1}$------ $b_{8}=$ Regression co-efficient of $x_{1}$ $\mathrm{x}_{8}$ to be estimated

$u=$ Error term

\section{Results and Discussion}

\section{Socio-economic characteristics of respondents}

The study shows that $23 \%$ of the participating farmers were between the ages of $46-50$ years, while the same age bracket was $19 \%$ for the non-participating farmers. The mean age of the participating farmers was 46 years while that of the non-participating farmers was 48 years. The result implies that most of the respondents were of middle age; signifying that both the categories of the respondents were within the agricultural productive age range of 30-50 years quoted by Food and Agriculture Organization (FAO, 1997; 2005). The result also revealed that $91 \%$ and $9.0 \%$ of the participating farmers were males and females respectively, while $99.0 \%$ and $1.0 \%$ of the non-participants were males and females respectively. This implies that the majority of the respondents were males which could be attributed to the current practice of purdah (women in seclusion) as the people in the area are predominantly Muslims. The 
dominance of males in farming agrees with Oyedele and Yahaya (2007). It also confirms the findings of Onuk (2008) which found that males constitute the majority in rice production because females are mostly involved in domestic work. However, the finding revealed that there were more females among the participants than with the non-participants. The study further revealed that $95 \%$ and $5 \%$ of the participating farmers were married and single respectively while $96.0 \%$ and $4.0 \%$ of the non-participating farmers were also married and single respectively. This could be attributed to the culture of the people in the area, which encourages early marriage. It could also be due to struggle to meet the needs of their families. Findings further shows that $23.7 \%$ and $17.1 \%$ of the participating and non-participating farmers had secondary education respectively. Also $5.8 \%$ of the participating farmers had tertiary education while only $4.7 \%$ of the non-participating had tertiary education. This implies that there were more educated farmers among the participating farmers and were aware of the importance of improved-inputs for increased agricultural productivity, which would facilitate the adoption of technologies promoted by the IFADCommunity Based Agricultural and Rural Development Project. Farinde et al. (2005) had identified literacy among other factors as a variable that positively influenced the use of improved agricultural inputs by farmers. The result of membership of cooperatives reveals that $85.7 \%$ of the participating farmers belong to cooperative associations while $68.5 \%$ constitute the numbers of the non-participating famers that belong to cooperative association. Finding also shows that $82.5 \%$ of the participating farmers had extension contact while only $39.4 \%$ of the non-participating farmers had contact with extension agent. The finding is in line with that of Atala (1980); Ogunfiditimi (1981); Agbelemoge et al. (2001) which confirmed independently the important role of extension agent in the diffusion and adoption of an innovation. The result also agrees with the findings of Isa et al. (2013) which stated that agricultural extension services helped famers to adopt innovations related to crop practices, better nutrition, improved health practices and better home living. 
Table 2: Socio-economic characteristics of sampled farmers

\begin{tabular}{lcc}
\hline & Participants & $\begin{array}{l}\text { Non- } \\
\text { participants }\end{array}$ \\
\hline Variables & Percentage \% & $\begin{array}{l}\text { Percentage } \\
\%\end{array}$ \\
\hline Age & & \\
$21-25$ & 2.3 & 3.2 \\
$26-30$ & 6.4 & 8.8 \\
$31-35$ & 7.9 & 10.0 \\
$36-40$ & 18.1 & 15.0 \\
$41-45$ & 16.9 & 15.0 \\
$46-50$ & 23.0 & 19.0 \\
$51>$ & 25.4 & 29.0 \\
Mean & 46 & 48 \\
Sex & & \\
Male & 91.0 & 99.0 \\
Female & 9.0 & 1.0 \\
Marital status & 95.0 & 96.0 \\
Married & 5.0 & 4.0 \\
Single & 2.9 & 1.2 \\
No formal educ. & 48.6 & 43.2 \\
Qur'anic educ. & 5.0 & 14.4 \\
Adult educ. & 14.0 & 19.4 \\
Primary educ. & 23.7 & 4.1 \\
Secondary educ. & 2.8 & \\
Tertiary educ. & 5.8 & \\
Membership of & & 68.5 \\
coop. & 85.7 & 31.5 \\
Yes & 14.3 & \\
No & & \\
& &
\end{tabular}

\section{Level of education}

The result of logit regression in Table 3 showed that level of education had a negative coefficient $(-0.309)$ and significant at 1 percent level of probability. This implies that the higher the level of education of the respondents, the less the probability of farmers participating in IFAD Community Based Agriculture and Rural Development Project. This confirms the findings of Okunmadewa (2002) who reported that education has a significant impact on farmers' efficiency in production. Farmer's literacy levels usually influences the decisionmaking and the adoption of innovation by farmers, which may bring about increase in productivity. Household size was also found to have a negative coefficient $(-0.041)$ and significant at $1 \%$ level of probability. The implication of this result is that the higher the number of people in a household the less the 
probability of farmers participation in the project. Farm size had a positive coefficient $(0.801)$ and was significant at $1 \%$ level of probability. The positive and significant influence of farm size implies that farmers with large farms size are likely to participate more in the project. This result is in agreement with the findings of Yahaya et al. (2013) who found farm size of the participating farmers to be highly significant at $1 \%$ level of probability. Sex was found to have a negative coefficient value $(-0.283)$ and was statistically significant at $1 \%$ level of probability. Membership of cooperative had a positive coefficient (0.547) and was statistically significant at $1 \%$ level of probability. This implies that membership of social organizations was an important factor in inducing farmers to participate in the IFAD-Community Based Agricultural and Rural Development Project. Access to credit also had a positive coefficient (1.213) and was statistically significant at $1 \%$ level of probability. It implies that access to credit of the individual's increases their probability of participation in the project. This finding is line with those of Oluwafemi et al. (2006) and Edi et al. (2007) who noted that access to credit, farm size and contact with extension influence participation. Extension contact had a positive coefficient $(0.283)$ and was statistically significant at $1 \%$ level of probability. This implies that the higher the number or frequency of the visit of extension agent to the farmers, the higher the probability level of participation and the adoption of recommended practices. This confirmed the findings of Oluwafemi et al. (2006) who found the socio-economic characteristics of farmers to have an influence on their level of participation in agricultural development programmes. However, age was inversely related to participation since the value of its coefficient was found to be negative $(-0.077)$ and was not statistically significant at either $1 \%$ or $5 \%$ level of probability. It therefore shows that the age of the farmer has no influence on farmers' participation in the project activities.

It was hypothesized that farmers' socio-economic factors have no influence on project participation. The finding showed that education with coefficient value of $(-0.309)$, household size $(-0.041)$, farm size $(0.801)$, sex $(-0.283)$, membership of cooperative (0.547) and extension contact (0.283) had significantly influenced farmers' participation at $1 \%$ level of probability. It is therefore concluded that farmers' socio-economic factors have influence on farmers' participation in the project; hence, the null hypothesis is hereby rejected. 
Table 3: Logit regression of socio-economic factors influencing farmers participation in IFAD-CBARDP

\begin{tabular}{lcccl}
\hline Variables & Coefficient & Standard Error & Valid Statistic & P value \\
\hline Constant & -1.535 & 0.173 & -8.870 & 0.000 \\
Age & -0.068 & 0.042 & -1.608 & 0.085 \\
Level of education & $-0.309^{*}$ & 0.051 & -6.110 & $0.000^{*}$ \\
Household size & $-0.041^{*}$ & 0.013 & -3.223 & $0.000^{*}$ \\
Farm size & $0.801^{*}$ & 0.254 & 3.151 & $0.000^{*}$ \\
Sex & $-0.283^{*}$ & 0.120 & -2.371 & $0.001^{*}$ \\
Membership of coop. & $0.545^{*}$ & 0.130 & 4.197 & $0.000^{*}$ \\
Access to credit & $1.213^{*}$ & 0.397 & 3.059 & $0.000^{*}$ \\
Extension contact & $0.583^{*}$ & 0.252 & 2.309 & $0.001^{*}$ \\
\hline
\end{tabular}

Likelihood Ratio Test Statistic $=943.117^{*} .{ }^{*} P \leq 0.01$

The result of the analysis of the major constraint to participation in the project revealed that inadequate capital $16.1 \%$, inadequate agricultural credits $11.3 \%$, inadequate storage facilities $15.7 \%$, limited access to market information $15.5 \%$, poor extension agent output $11.3 \%$, inadequate agricultural insurance $10.7 \%$, poor leadership $5.7 \%$, lack of awareness $5.5 \%$ and socio-cultural barrier $3.5 \%$ as the factors affecting the effective participation in IFADCBARDP in the study area. This supports the findings of Akpabio (2007) that inadequate credit facilities and poor utilization of credit advances are factors constraining effective beneficiaries' participation in women Non-Governmental Organizations (NGOs). The reported socio-cultural barrier that constrained participation was attributed to the fact that the majority of the respondents were male with only a few female participants. Women participation in some agricultural activities is limited due to socio-cultural practices. 
Table 4: Major constraints to effective participation in IFAD-CABARDP by the farmers

\begin{tabular}{lcl}
\hline Variables & Percentage \% & Rank \\
\hline Inadequate capital & 16.2 & $1^{\text {st }}$ \\
Inadequate agricultural credit & 16.0 & $2^{\text {nd }}$ \\
Inadequate storage facilities & 15.7 & $3^{\text {rd }}$ \\
Limited market information & 15.5 & $4^{\text {th }}$ \\
Poor Extension agents outputs & 11.3 & $5^{\text {th }}$ \\
Inadequate agric. insurance & 10.7 & $6^{\text {th }}$ \\
Poor leadership & 5.6 & $7^{\text {th }}$ \\
Lack of awareness & 5.5 & $8^{\text {th }}$ \\
Socio-cultural barrier & 3.5 & $9^{\text {th }}$ \\
Total & 100 & \\
\hline
\end{tabular}

\section{Conclusion and Recommendation}

The combined influence of socio-economic variables (level of education, household size, farm size, sex, membership of cooperative, access to credit and extension contact) have made positive and significant contributions to farmers participation in IFAD-CBARDP activities at $1 \%$ level of probability. However, age of the farmers was not significant at either $1 \%$ or $5 \%$ level of probability. The study further reveals that inadequate capital, inadequate agricultural credit, inadequate storage facilities and limited market information among other factors had constrained the effective participation of farmers in the project. It is recommended that Government and non-governmental organizations dealing with extension should motivate farmers through the provision of more subsidy packages and making credit facilities accessible. This would enhance greater participation in the project and increase crop output. Government should provide incentive measures to the farmers that will reduce the effects of the dwindling market prices of agricultural commodities. In addition, extension workers should assist farmers to form viable co-operative associations and where they are in existence, efforts should be made to strengthen them for easy access to credit, farm inputs and markets for their agricultural products.

\section{References}

Agbelemoge, A., Adedoyin, S.F. and Oladoyin, S.D. (2001). Farmers Related Factors and Adoption of Cocoa Rehabilitation Technology in Oluyole Local Government Area of Oyo State Nigeria. Moore Journal of Agricultural Research, IAR\&T, Moore Plantation, Ibadan. 
Akpabio, I.A. (2007). Women NGOs and Rural Women Empowerment Activities in the Niger Delta, Nigeria. Journal of Environment, Development and Sustainability. Springer Netherlands. Vol. 11(2) Pp135-136.

Andrea, B. (2014). Linking Smallholder Farmers to Markets and the Implication for Extension and Advisory Services. MEAS Discussion Paper no. 4. United State Agency for International Development. https://mail.google.com/mail/?shva=1

Aref, F. Marof, R. and Sarjit, S.G. (2010). Community capacity building:A review of its implications in tourism development. Journal of American Science 6(1): $172-180$.

Atala, T.K. (1980). Factors Affecting Adoption of Agricultural Extension Innovations, Usage of Sources of Information and Level of Living of Two Nigerian Villages: Unpublished M.Sc. Theses, IOWA State University, Ames, USA.

Atala, T.K. and Hassan, M.B. (2012). Adopted Village Concept and Vision 20: 2020. Paper presented at the North West Zonal REFILS Workshop, held at the Institute for Agricultural Research, Ahmadu Bello University, Zaria. 23-24 Feb. 2012.

Babatunde, O. (2006). Differential Poverty Reduction Impact of Small-Scale Irrigated Development between its Beneficiaries and Non-beneficiaries in Nigeria. Technical Report on the Agropolis Award

Bukar, T. (2005). Critical Challenges and Problems of Effective Programme/Project Implementation. Paper presented in a Workshop for Western and Central Africa, Bamaco, Mali $8^{\text {th }}-11^{\text {th }}$ March.

Edi, D., Paola, G., Ford, R. and Samuel, T. (2007). Factors Affecting Farmer's Participation in Agro-environmental Measures: A Northern Halian Perspectives. Journal of Agricultural Economics, Princeville Publishers, Rome, Italy 59(1), Pp. 114-131.

Farinde, A.J., Ogunsumi, L.O., Omoyajowo, A.O, and Oyegbami, O. (2005). Farmer Involvement in the Transfer of Cassava Technologies in Southwest Nigeria. International journal of Applied Agriculture and Research, $1: 1324$

Food and Agriculture Organization (FAO) (1997). Category to Land and Water Information. Nigerian National Report on Water Resource Development Food and Agriculture Organisation. An FOA Publication Rome, Italy, Pp. 190-201.

Food and Agriculture Organization (FAO) (2005). AQUASTAT Database. http:/www.fao.org/waicent/faointo/agricult/ag/w/aquastat/site visited $21 / 01 / 2014$ 
Gujrati (2004). Basic Econometrics, $4^{\text {th }}$ Edition. Published by McGraw-Hill Pp 598-607

Internationl Day for the Eradication of Poverty, (IDEP) (2006). Working Together Out of Poverty, (Abuja, Nigeria).

International Fund for Agricultural Development (IFAD) (2013). COSOP MidTerm Review

Operations. Ifad.org/web/ifad/operations/country/home/tags/Nigeria02/02/2015; 5:11

Isa, A.G., Okeh, B.C and D.O. Oni (2013). Effects of Agricultural Extension Services on Farmers Crop Production in Jigawa State, Nigeria. Journal of Vocational and Technical Education Vol. 8, No. 1 Pp 28-30.

Ogunfiditimi, T.O. (1981). Adoption of Improved Farm Practices. A Choice under Uncertainty. Indian Journal of Extension Education. 17(2) 30 35.

Okunmadewa, F. Y. (2002). Poverty Reduction and the Nigeria Agricultural Sector. Published by Elshaddai Global Ventures Ltd Mokola Ibadan Nigeria.

Oluwafemi, O. O., Ezekiel, O. I and Herman D. V. (2006). Assessing Irrigation Project Performance for Sustainable Irrigation Policy Reform. A Journal of Irrigation and Drainage System. Vol.20.Published by Springer Netherlands, Pp 303-315

Onuk G.E. (2008). Meeting the Challenges of Rice Demands through Children and Youth-in-Agriculture. A Paper Presented at $10^{\text {th }}$ Annual Conference of the National Research and Development, Network of Children and Youth-in-Agriculture Programme (CYIAP).

Oyedele, O.O. and Yahaya, M.K. (2007). Technical Information Needs in Improves Citrus Production Techniques of Farmers in Southwestern Nigeria. Journal of Agricultural extension, vol. 10, pp, 168-175.

Schubert, R. (1994). Poverty in Developing Countries, its Definition, Extent and Implications. Economics Volume 49/50.

Yahaya, H., Luka, E.G., Salau, E.S. and Idoko, F.A. (2013). Rice Production under the Youth Empowerment Scheme in Nasarawa State, Nigeria. Journal of Agricultural Extension Vol. 17(2) Pp. 186-193. 